\title{
SYARAT PERLU DAN SYARAT CUKUP SOLUSI POSITIF EVENTUAL SISTEM PERSAMAAN DIFERENSIAL LINIER HOMOGEN \\ ORDE SATU
}

\author{
Yulian Sari \\ Prodi Pendidikan Matematika Universitas Riau Kepulauan
}

\section{ABSTRAK}

Artikel ini mengkaji solusi atau penyelesaian sistem persamaan differensial linier homogen orde satu

$$
\dot{\mathbf{x}}(t)=A \mathbf{x}(t), \quad \mathbf{x}(0)=\mathbf{x}_{0}
$$

dimana $A \in \mathbb{R}^{n \times n}, \mathbf{x}:[0, \infty) \rightarrow \mathbb{R}^{n}$ yaitu $\mathbf{x}(t)$ agar selalu bernilai nonnegatif. Untuk sistem (1) dengan $\mathbf{x}_{0} \geqslant 0$, jika matriks $A$ adalah eksponensial positif eventual, maka solusi $\mathbf{x}(t)$ untuk sistem tersebut dinamakan sebagai solusi positif eventual. Sifat-sifat agar matriks $A$ adalah matriks eksponensial positif eventual digunakan dalam pembahasan. Artikel ini merupakan kajian kembali tentang syarat cukup dan menambahkan hasil analisis tentang syarat perlu agar solusi $\mathbf{x}(t)$ adalah solusi positif eventual dengan $\mathbf{x}_{0} \geqslant 0$ adalah $A+a I$ adalah matriks positif eventual untuk suatu $a \geq 0$.

Kata Kunci : solusi positif eventual, matrik eksponensial positif eventual, differensial linier homogen orde satu.

\section{Latar Belakang}

Diberikan suatu sistem persamaan diferensial linier homogen orde satu sebagai berikut.

$$
\dot{\mathbf{x}}(t)=A \mathbf{x}(t), \quad \mathbf{x}(0)=\mathbf{x}_{0}
$$

dimana $A \in \mathbb{R}^{n \times n}, \mathbf{x}:[0, \infty) \rightarrow \mathbb{R}^{n}$, dan $\dot{\mathbf{x}}=\frac{d \mathbf{x}}{d t}=\left[\begin{array}{c}\frac{d x_{1}}{d t} \\ \vdots \\ \frac{d x_{n}}{d t}\end{array}\right]$. Dalam literatur [2] dinyatakan bahwa solusi sistem (1) adalah

$$
\mathbf{x}(t)=e^{t A} \mathbf{x}_{0}
$$

Perlu diperhatikan bahwa solusi (2) dapat bernilai nonnegatif atau negatif. Salah satu cara agar $\mathbf{x}(t)$ bernilai nonnegatif adalah $e^{t A}>0$ dan $\mathbf{x}_{0} \geqslant 0$. Dalam situasi tertentu, $e^{t A}$ tidak selalu positif untuk setiap $t \geq 0$. Matriks $A \in \mathbb{R}^{n \times n}$ yang mempunyai sifat ada $t_{0} \in[0, \infty)$ sedemikian sehingga $e^{t A}>0 \forall t \geq t_{0}$ disebut sebagai matriks eksponensial positif eventual [2]. Untuk sistem (1) dengan $\mathbf{x}_{0} \geqslant 0$, jika matriks $A$ adalah eksponensial positif eventual, maka solusi $\mathbf{x}(t)$ untuk sistem tersebut dinamakan sebagai solusi positif eventual [3].

Syarat cukup bagi solusi sistem (1) adalah solusi positif eventual telah dikaji dalam [1]. Tulisan ini memaparkan kembali syarat cukup tersebut dan menambahkan syarat perlu agar solusi sistem (1) adalah solusi positif eventual.

\section{Notasi dan Definisi}

Definisi 1. [1] Untuk sebarang matriks $A \in \mathbb{R}^{n \times n}$,

$$
e^{t A}=\sum_{k=0}^{\infty} \frac{(t A)^{k}}{k !}=I+t A+\frac{(t A)^{2}}{2 !}+\frac{(t A)^{3}}{3 !}+\cdots
$$


didefinisikan sebagai matriks eksponensial dari $A$, dimana $t \in \mathbb{R}$, dan $I \in \mathbb{R}^{n \times n}$ adalah matriks identitas.

Definisi 2. [2] Misalkan $A=\left[a_{i j}\right] \in \mathbb{R}^{n \times n}$. Matriks A dikatakan:

1. positif, ditulis $A>0$, jika $a_{i j}>0$ untuk setiap $i$ dan $j$

2. nonnegatif, ditulis $A \geqslant 0$, jika $a_{i j} \geq 0$ untuk setiap $i$ dan $j$

3. nonnegatif eventual, dinotasikan dengan $A \geqslant_{v} 0$, jika terdapat bilangan bulat positif $k_{0}$ sedemikian sehingga $A^{k} \geqslant 0$ untuk setiap $k \geq k_{0}$. Bilangan bulat positif terkecil $k_{0}=$ $k_{0}(A)$ disebut sebagai indeks pangkat dari $A$

4. positif eventual, dinotasikan dengan $A>_{v} 0$, jika terdapat bilangan bulat positif $k_{0}$ sedemikian sehingga $A^{k} \geqslant 0$ untuk setiap $k \geq k_{0}$. Bilangan bulat positif terkecil $k_{0}=$ $k_{0}(A)$ disebut sebagai indeks pangkat dari $A$.

5. nonnegatif eksponensial, jika

6. positif eksponensial, jika

$$
e^{t A}=\sum_{k=0}^{\infty} \frac{t^{k} A^{k}}{k !} \geqslant 0 \forall t \geq 0,
$$

$$
e^{t A}=\sum_{k=0}^{\infty} \frac{t^{k} A^{k}}{k !}>0 \forall t>0,
$$

7. eksponensial nonnegatif eventual, jika $\exists t_{0} \in[0, \infty)$ sedemikian sehingga $e^{t A} \geqslant 0$, $\forall t \geq t_{0}$

8. eksponensial positif eventual, jika $\exists t_{0} \in[0, \infty)$ sedemikian sehingga $e^{t A}>0, \forall t \geq t_{0}$.

\section{Pembahasan dan Hasil}

Teorema 1. [2] Misalkan $A \in \mathbb{R}^{n \times n}$. Pernyataan berikut ekivalen:

(i) $A+$ aI merupakan matriks positif eventual untuk suatu $a \geq 0$.

(ii) A merupakan matriks eksponensial positif eventual.

Teorema 2. Misalkan diberikan sistem $\dot{\mathbf{x}}(t)=A \mathbf{x}(t)$ dengan syarat awal $\mathbf{x}(0)=\mathbf{x}_{0}$. Matriks $A+$ al adalah matriks positif eventual untuk suatu $a \geq 0$ jika dan hanya jika solusi $\mathbf{x}(t)$ untuk sistem tersebut adalah positif eventual untuk setiap $\mathbf{x}_{0} \geqslant 0$.

\section{Bukti}

$(\Rightarrow)$ [3] Misalkan $A+a I$ adalah matriks positif eventual untuk suatu $a \geq 0$, maka berdasarkan Teorema 1, matriks $A$ adalah matriks eksponensial positif eventual. Akibatnya $\exists t_{0} \in[0, \infty)$ sedemikian sehingga $\mathrm{e}^{t A}>0 \forall t \geq t_{0}$. Karena $\mathbf{x}_{0} \geqslant 0$,

maka

$$
\mathbf{x}(t)=\mathrm{e}^{t A} \mathbf{x}_{0}>0 \quad \forall t \geq t_{0}
$$

Sehingga solusi sistem $\dot{\mathbf{x}}(\mathrm{t})=A \mathbf{x}(\mathrm{t})$ dengan syarat awal $\mathbf{x}(0)=\mathbf{x}_{0}$ adalah positif eventual.

$(\Leftarrow)$ Misalkan $\dot{\mathbf{x}}(t)=A \mathbf{x}(t)$ dengan syarat awal $\mathbf{x}(0)=\mathbf{x}_{0}$ dan solusi $\mathbf{x}(t)$ adalah solusi positif eventual, maka berdasarkan definisi pada latar belakang, mestilah $A$ adalah matriks 
eksponensial positif eventual. Karena $A$ adalah matriks eksponensial positif eventual, berdasarkan Teorema 1, maka $A+a I$ adalah matriks positif eventual untuk suatu $a \geq 0$.

Akibatnya, terbukti bahwa matriks $A+a$ I adalah matriks positif eventual untuk suatu $a \geq 0$ jika dan hanya jika solusi $\mathbf{x}(\mathrm{t})$ untuk sistem tersebut adalah positif eventual untuk setiap $\mathbf{x}_{0} \geqslant$ 0 .

\section{Kesimpulan}

Berdasarkan uraian yang telah dibuat dan dibahas, maka syarat cukup dan syarat perlu agar solusi sistem $\dot{\mathbf{x}}(\mathrm{t})=A \mathbf{x}(\mathrm{t})$ dengan syarat awal $\mathbf{x}(0)=\mathbf{x}_{0} \geqslant 0$ positif eventual adalah matriks $A+a I$ positif eventual untuk suatu $a \geq 0$.

\section{Referensi}

[1] Boyce, W. E dan R. C. Diprima. 2001. Elementary Differential Equation and Boundary Value Problems. Eight edition. John Wiley. New York.

[2] Noutsos, D. dan M. J. Tsatsomeros. 2008. Reachability and Holdability of Nonnegative States. SIAM Journal on Matrix Analysis and Applications. 30:700-712.

[3] Sari, Yulian. 2011. Solusi Positif Eventual Sistem Persamaan Differensial Linier Homogen Orde Satu. Prosiding, Seminar Nasional Matematika yang diselenggarakan oleh FMIPA Unand, tanggal 21 Juni 2011. Padang: Universitas Andalas. 